of the periodicities. The results have a correlation of 0.504 with the observed values. From about thirty independent values (the figures are smoothed over five months) this makes a real connexion fairly probable (if it has not been introduced by the 'adjustments' of scale), but is far from justifying the claim that it is "obvious and certain". A further, real, forcast is given on the same basis for 1952-59, and it is interesting to compare the forecast temperatures with the observed as far as they are available (the observed temperatures have been supplied by the Meteorological Office, Harrow). Both forecast $\left(F^{\prime}\right)$ and observed $(O)$ temperatures are smoothed over five months.

\begin{tabular}{|c|c|c|c|c|c|c|c|}
\hline \multirow[t]{2}{*}{1952} & $\begin{array}{cc} & \text { Jan. } \\
F & 39 \cdot 1 \\
O & 42 \cdot 0\end{array}$ & $\begin{array}{l}\text { Feb. } \\
40 \cdot 4 \\
44 \cdot 6\end{array}$ & $\begin{array}{l}\text { Mar. } \\
47 \cdot 3 \\
49 \cdot 2\end{array}$ & & & $\begin{array}{l}\text { May } \\
66 \cdot 2 \\
64 \cdot 4\end{array}$ & $\begin{aligned} \text { June } & \\
72 \cdot 6 & \circ \\
71 \cdot 2 & \circ\end{aligned}$ \\
\hline & $\begin{array}{cc} & \text { July } \\
F & 75 \cdot 7 \\
O & 73 \cdot 6\end{array}$ & $\begin{array}{l}\text { Aug. } \\
73 \cdot 9 \\
72 \cdot 0\end{array}$ & $\begin{array}{l}\text { Sept. } \\
66 \cdot 2 \\
66 \cdot 2\end{array}$ & & & $\begin{array}{l}\text { Nov. } \\
44 \cdot 2 \\
50 \cdot 6\end{array}$ & $\begin{array}{l}\text { Dec. } \\
35 \cdot 2^{\circ} \mathrm{F} \text {. } \\
45 \cdot 2{ }^{\circ} \mathrm{F} \text {. }\end{array}$ \\
\hline & $\begin{array}{l}\mathrm{Jan} \\
35 \cdot 3 \\
43 \cdot 6\end{array}$ & $\begin{array}{l}\text { Feb. } \\
35 \cdot 9 \\
45 \cdot 2\end{array}$ & $\begin{array}{l}\text { Mar. } \\
43 \cdot 1 \\
51 \cdot 4\end{array}$ & $\begin{array}{l}\text { April } \\
54 \cdot 2 \\
58 \cdot 2\end{array}$ & $\begin{array}{l}\text { May } \\
63 \cdot 7 \\
65 \cdot 8\end{array}$ & $\begin{array}{l}\text { June } \\
72 \cdot 4 \\
71 \cdot 4\end{array}$ & $\begin{array}{l}\text { July } \\
78 \cdot 9 \\
74 \cdot 2\end{array}$ \\
\hline
\end{tabular}

Considering the extensive smoothing, while an error of less than $3^{\circ} \mathrm{F}$. might be regarded as a good forecast, more than $3^{\circ} \mathrm{F}$. would be poor, and more than $5^{\circ} \mathrm{F}$. bad. The forecast temperatures are reasonably accurate for the first ten months of 1952 and for May and June 1953, but from November 1952 to March 1953 and July 1953 they fail badly. Twelve good against six bad forecasts suggest that, while there may be some basis for Dr. Abbot's predictions, it is far from sound, and certainly does not justify the issue of a forecast.

$$
\text { C. E. P. Brookg }
$$

\section{FEDERAL FOREST ADMINISTRATION IN MALAYA}

\section{ANNUAL REPORT FOR 1951}

$\mathrm{T}$ $\mathrm{HE}$ annual forest reports of the Federation of Malaya for 1949 and 1950 gave testimony to the remarkable progress being made by the Forest Department in spite of the Japanese occupation during the Second World War and the present-day troubles (see Nature, 167, 679 (1951), and 169, 700 (1952)). The report for $1951^{*}$ by the director of forestry, Mr. J. P. Edwards, shows that the progress has been continued.

Further to this, however, the report is of historical interest in that, in an introduction on the history of the Malayan forests and their development, material of vital importance is recorded which has so often been lost in other countries in the past through failure of records. As early as 1883 a small department was set up in the Straits Settlement under the director of gardens. Four years later Mr. H. N. Ridley became director, and he carried out an extensive programme of reservation of valuable forests which would otherwise have been entirely destroyed during the 1910 rubber boom in Malacca ; reservation of forests on the higher hills in Penang was also effected. Control of the forests was assumed by the land officers in 1895 and continued until 1901. The forests of the former Federated Malay States had also been

* Report on Federal Forest Administration in the Federation of Malaya for the Year 1951. By J. P. Edwards. Pp. 67+4 plates
(Kuala Lumpur: Govt. Printer, 1952.) 2 Malay dollars or $48.8 d$. in charge of the district land officer in Perak, Selangor and Negri Sembilan.

The introduction of an up-to-date forest conservancy resulted from a visit of a distinguished Indian forest officer, Mr. H. C. Hill (later inspectorgeneral of forests in India), in 1900, who submitted a comprehensive report on forest administration in the Colony. This was followed by the appointment in October 1901 of Mr. A. M. Burn-Murdoch (from the Burma Forest Department) as the first chief forest officer, Federated Malay States and Straits Settlements. Burn-Murdoch laid the foundations of the Department as it is to-day. The Department has been fortunate in having had several first-class successors to carry on the work so effectually. Forest research was started with the appointment in 1918 of the late Dr. F. W. Foxworthy as forest research officer. Not only did Foxworthy place the branch in a strong position which has since been added to (including recently a new up-to-date laboratory for research on wood anatomy, mensuration and timber); but his work also became widely known in other parts of the world. E. P. Sterbbing

\section{TERTIARY FLORAS}

$\mathrm{T}$ THE rich fossil flora of the well-known Middle Tertiary lake bed at Florissant, Colorado, some 8,500 ft. up in the Central Rocky Mountain regions, is notable for its very numerous species and for the excellent preservation of the plant impressions of twigs and leaves, with some fruits, seeds and flowers : there is also an abundant fauna, chiefly of insects. The general features of the flora are well known from earlier descriptions by Lesquereux, Cockerell, Knowlton and others. A recent monograph by Dr. MacGinitie*, in the finely produced series of the Carnegie Institution of Washington, gives a revised and extended account of the flora, with a full analysis of its relationships with other floras of the remarkable North American Tertiary series, and special interest is attached to the use of the Florissant plant popu. lation as a climatic indicator, and in dating the lake bed, the age of which has been uncertain.

A glance at the list of synonyms and changes of name indicates the wide extent of the taxonomic revision involved. From earlier accounts, some 258 species have been described; but this revision reduces the number of well-established species to 114. Of these, 110 are species of seed plants (mostly trees and shrubs) representing 84 genera from 44 families, and 20 new species are included. The most abundant plant in the flora is Fagopsis longifolia, belonging to an extinct genus which so far as is known is peculiar to Florissant: this genus has previously been included in the Fagaceae, but is now referred by MacGinitie to the Betulaceæ on the evidence of the attached "cones". Among other abundantly represented species are Zelkova drymeja, Chamaecyparis linguaefolia, Typha lesquereuxi, Populus crassa, Sequoia affinis, Cercocarpus myricaefolius and Athyana haydenii. Using the fossil species the relationships of which with modern species are reasonably clear, a comparison is made with living floras : and the picture of the Florissant flora which emerges is one of predominantly warm temperate

- Carnegie Institution of Washington. Contributions to Paleontology. Fossil Plants of the Florissant Beds, Colorado. By Harry D. MacGinitle. Pp. iii $+198+75$ plates. (Publication No. 599.) (Washington, cloth, 5.75 dollars. 
facies. The living species most similar to the majority of the fossil species are found in floras of the south-western interior of North America, principally in the Texas-Mexican region; but there are also plants at Florissant the present-day affinities of which are with Chinese, Californian and South American species. For example, the fossil species Lomatia lineata, which is identified from both foliage and fruit, is closely similar to the living South American $L$. ferruginea, and provides reliable evidence for a former more northerly spread of the Proteaceæ, which to-day is characteristically a family of the southern hemisphere. The com. parison between the fossil species and these living representatives forms the basis of a reconstruction of the environment: the wide range and large number of species used gives conviction to the conclusion that the climate was probably a warm temperate one with a pronounced dry season, and this has had independent corroboration from a study of the fossil Diptera of the lake beds, as well as from the ecological indications of the associated sediments. The age of the lake beds is also deduced from the flora and is established as early Oligocene, after comparison with the Colorado Green River flora of mid-Eocene age and the Oregon Bridge Creek flora of Oligo-Miocene age, the two North American Tertiary floras of this region which show the most significant similarities with the Florissant ftora. Again, there has been corroboration of this from a study of the scanty vertebrate remains and from the lithology of the deposits. While many of the species differences between these floras are no doubt due to extinction and to migration, it is clear that there are at least some species in the Florissant flora which are derivative from Green River forms, and the resemblances may, indeed, be due to continuous floristic development in the same area; for example, this may well have been the case with the species of the Asiatic genus Zelkova in the floras.

Though lacking any cuticular studies, which, indeed, may not be practicable with this material, such revision and analysis of a Tertiary flora bids fair to establish some of the history of the angiosperms, both of lineages and migrations, on a more secure basis, as well as offering useful indications of geological age and climate.

\section{REGISTER OF RESEARCH IN THE SOCIAL SCIENCES}

$\mathrm{T}$ $\mathrm{HE}$ issue of the "Register of Research in the Social Sciences for 1952-3" (pp. 213; 1953 ; 25s.), published by the Cambridge University Press for the National Institute of Economic and Social Research, London, shows that the total amount of research of which particulars are given to the Institute is still increasing. This appears, however, to be due to the fact that the number of new entries each year greatly exceeds those which are removed from the "Register" because they are completed. During the preceding three years, the number of new entries has, in fact, fallen from 245 to 201 , and although the number completed has risen from 121 to 140 , the total number of entries has increased in the same period from 334 to 648 .

This seems to show that research work in the social sciences tends to be a somewhat protracted

process. It is obvious that most of the projects are being continued over longer periods than three years; but it remains to be seen how long it takes before the first substantial results are usually obtained from work of this kind.

Too much importance should not, however, be attached to these figures, or the conclusions based on them. The scope of the "Register" and of the projects listed in it is very wide indeed; the range is from "Soviet Law and Government" and "The Pure Science of Politics", which may be deemed to provide a lifetime of work for several scholars, to "What is an Office Manager ?" and "A Forecast of Effects of Economies in London Telephone Directory Services", which are at least much more limited undertakings. The compilation of the "Register" is an exceedingly difficult task; but it will not be possible to use it for any more fundamental purpose than a mere list of work in progress unless the editors decide to prune the entries more rigorously.

\section{DISTRIBUTION OF THE BRUSH POSSUM IN TASMANIA}

\section{By Dr. ERIC R. GUILER}

Department of Zoology, University of Tasmania

$T$ HE brush possum Trichosurus vulpecula (Kerr) is found in most parts of Tasmania. In some localities, however, the distribution of the species is partly restricted by the absence of trees. One of the most interesting features of the biology of this species is the distribution of the black and grey colour phases. Pearson ${ }^{1}$ found that there was no climatological reason for the apparently well-defined distribution of the black variety; but a recent examination of new material shows an ecological correlation of the distribution of the two colour phases.

The brush possum forms an important part of the Tasmanian fur industry, and skins collected during a short open season are liable to royalty. The royalties received are entered on a return by an officer, usually a policeman; acting on behalf of the Animals and Birds Protection Board. The statements are sent to police headquarters at Hobart. I am indebted to the Police Department for allowing me to peruse the returns, which show the number of water-rat, kangaroo, wallaby, ringtail and brush possum skins taken and the localities from which they came. The two colour phases of the animal are sufficiently important economically to warrant classification on the return as 'black possum' and 'grey possum'. Hence it is possible to obtain, assuming the form to be correctly entered, a reasonably accurate picture of the distribution of the two colour phases. Owing to the destruction of all records prior to 1947, those for the year 1949 are the only ones available. The years 1947, 1948 and 1950-51 were closed seasons. The total number of possum pelts taken is given in Table 1.

Owing to the lack of satisfactory evidence of place of capture, the figures, on which the distribution

Table 1

Number of Trichosurus pelts taken during the 1949 open season in

\begin{tabular}{llll}
\multicolumn{4}{c}{ Tasmania and the number included in the present survey : } \\
& Black & Grey & Total \\
No. branded & 22,792 & 68,023 & 90,815 \\
No. included in present survey & 11,988 & 23,250 & 35,238
\end{tabular}

